\title{
Aplicações das políticas educacionais e as dificuldades de aprendizado do ensino de ciências: o caso da Escola Santo Antônio
}

\author{
Aplications of Educational Policy and Learning difficulties of Science Education: \\ the case of the School Santo Antonio
}

\author{
João Batista Augusto de Oliveira ${ }^{1}$, Viviane Furtado Gomes² ${ }^{\text {, José Roberto Lopes }}{ }^{3}$ \\ e Cilene Maria Lima Antunes Maciel ${ }^{4}$ \\ ${ }^{1}$ Graduado em Licenciatura em Ciências da Natureza \\ ${ }^{2}$ Graduado em Licenciatura em Ciências da Natureza \\ ${ }^{3}$ Mestre em Desenvolvimento Local, Instituto Federal de Educação e Tecnologia de Jaciara-MT \\ ${ }^{4}$ Doutora em Ciências da Educação, Professora da Universidade de Cuiabá- MT
}

\begin{abstract}
RESUMO:
O presente trabalho teve como objetivo avaliar a aprendizagem na disciplina de Ciência dos alunos de uma escola de Ensino Fundamental no Município de Jaciara, e como o livro didático era utilizado, assim como outros recursos tecnológicos.

A formação docente, sua metodologia, ansiedade e perspectiva diante de uma clientela desinteressada e desmotivada, e como as Políticas Publicas Educacionais podem contribuir para amenizar, talvez eliminar essas dificuldades.

Palavras-chaves: Ensino de Ciências. Formação Docente. Práticas Pedagógicas
\end{abstract}

\section{ABSTRACT:}

The present work had as objective to evaluate the learning education in the discipline of Science students of an elementary school in the municipality of Jaciara, and as the textbook was used, as well as other technological resources. The teacher education, its methodology, anxiety and perspective before a disinterested clientele and disheartened, and as Public Educational policies can help to ease, maybe eliminate these difficulties.

Keywords: Science education. Teacher education. pedagogical practices 


\section{Introdução}

Uma retrospectiva histórica da educação básica no Brasil, principalmente nas décadas de 70 e 90, percebe-se que o país viveu um processo de intensos questionamentos sobre as condições de acesso e permanência do aluno na escola, suscitando medidas de reorganização e recomposição da estrutura de ensino. Neste caso, o ensino de Ciências, que antes era somente visto nas universidades, chegou ao Ensino Fundamental, primeiramente nas últimas séries, e na década de 90 a partir $5^{\underline{a}}$ a $8^{\underline{a}}$ serie (hoje $6^{\circ}$ ao $9^{\circ}$ ano), o que constitui passos importantes para ciência.

Nesse sentido, houve medidas significativas no ensino brasileiro, como a reestruturação da educação. Com a criação dos Parâmetros Curriculares Nacionais- PCNs em 1998 e alterações na Legislação Brasileira de Educação LDBE 9394/96, na tentativa de melhorar a aprendizagem dos alunos. O surgimento do Ciclo de Formação Humana pretendeu-se a superação do sistema de séries, com sua avaliação classificatória e excludente. Diversas experiências pedagógicas na perspectiva dos ciclos foram registradas no Brasil, antes de sua implantação, assumindo contornos diferenciados, conforme as condições estruturais e políticas estabelecidas em cada contexto escolar.

Segundo a Secretaria de Educação de Estado de Mato Grosso (2014); a proposta do ciclo de formação humana, já completou treze anos de implantação oficialmente nas escolas públicas estaduais. Embora a organização escolar por ciclos não seja algo tão recente assim na prática pedagógica de muitos professores, alguns vivem constantemente angustiados sobre como trabalhar com a organização do sistema em Ciclos de Formação Humana, principalmente nas escolas que recebem alunos para serem reenturmados na forma idade-ciclo.

Esta pesquisa surge em um momento de muitas inquietações no ano de 2014 durante o estágio de observação pelos graduandos do curso de Ciências da Natureza, durante a observação das aulas Ciências na escola Santo Antônio do município de Jaciara-MT. Neste momento surgiu as dúvidas de como as Políticas Educacionais interferem na aprendizagem dos alunos e nas práticas pedagógicas em sala de aula e como a comunidade escolar reage com estas modificações?

A pesquisa foi elaborada sobre como as aplicações das Políticas Educacionais interferem para sanar as dificuldades de aprendizagem do ensino de Ciência, dados coletados conforme a observação durante o estágio. Buscou-se, então, obter respostas através de um diagnóstico os resultados das entrevistas com a comunidade escolar para compreender o cotidiano vivido pelos alunos, e o porquê, de eles conseguirem ou não aprender ciências.

Este texto de Trabalho de Conclusão de Curso está estruturado da seguinte forma: Tratou-se inicialmente da Retrospectiva Histórica da Escola Estadual Santo Antonio. Descreveu-se sobre o funcionamento da escola como proposta de fazer uma reflexão sobre as concepções de educação e as Políticas Educacionais, apoiando-se em pensadores como: José Azanha (2006), Mário Contreras (2012), FREIRE (1997), Nóvoa (2007).

Optou-se por escrever um pouco a retrospectiva do ensino de Ciências no Brasil, quais as dificuldades de compreensão do conteúdo e a importância das práticas pedagógicas do docente na assimilação de conceitos pelos alunos. Destacou-se o procedimento didático, os recursos disponíveis na escola, e a escolha do Livro didático como único mediador e a intervenção das Políticas Educacionais.

Abordou-se os percursos metodológicos no contexto e sujeito da pesquisa, apresentando os objetivos, o caminho metodológico, o contexto e sujeitos da pesquisa, que foram estruturados no campo da abordagem qualitativa, que privilegia a descrição da realidade e a coleta de dados no 
ambiente onde acontece o fenômeno, preocupou-se em apresentar, junto com a visão do pesquisador, o ponto de vista do sujeito/participante da pesquisa.

As análises dos dados coletados e resultados alcançados na pesquisa foram apresentados tentando conjugar informações coletadas por meio de entrevistas, observações e análise documental e, em seguida, as conclusões.

\section{Reflexão do cotidiano escolar}

\subsection{Retrospectiva da Escola Santo Antonio}

A Escola Estadual "Santo Antônio" desde o ano de sua fundação, em 1979 até o final de 1982 funcionou com o nome de escola Municipal de $1^{\circ}$ Grau "Santo Antônio", mantida pela Prefeitura Municipal de Jaciara. Em 1983, a referida Escola mudou de mantenedora passando a denominar-se Fundação Escola de $1^{\circ}$ Grau "Santo Antônio", vinculada diretamente à Fundação Educacional Júlio S. Muller, com sede no município de Cuiabá-MT, capital de Mato Grosso. No final do ano de 1995, mudou-se de mantenedora novamente, passando à Rede Estadual e com denominação Escola Estadual "Santo Antônio", conforme decreto de criação n 846 de 02/04/1996, e em consonância com o art. 56 e parágrafo único ambos da resolução 150/99 - CEE/MT.

A Escola Estadual Santo Antônio, localiza-se na Rua Bartira, 703, Bairro Santo Antônio, Jaciara-MT. Criada pelo decreto $n^{\circ} 842$, publicado no Diário Oficial, $n^{\circ} 21.873$ de 02/04/1996. Tendo sido autorizada a funcionar a Educação Infantil e o Ensino Fundamental de I a IV e pela portaria ${ }^{\circ}$ 123/99 SEDUC/MT, publicada no Diário Oficial n 22.595 de 09/03/1999 e, V a VIII conforme resolução 040/01 - CEE/MT.

Segundo Projeto Político Pedagógico (PPP) desta escola vale ressaltar que a escrituração, o espaço físico e o endereço da escola, em suas várias denominações, são os mesmos que eram quando

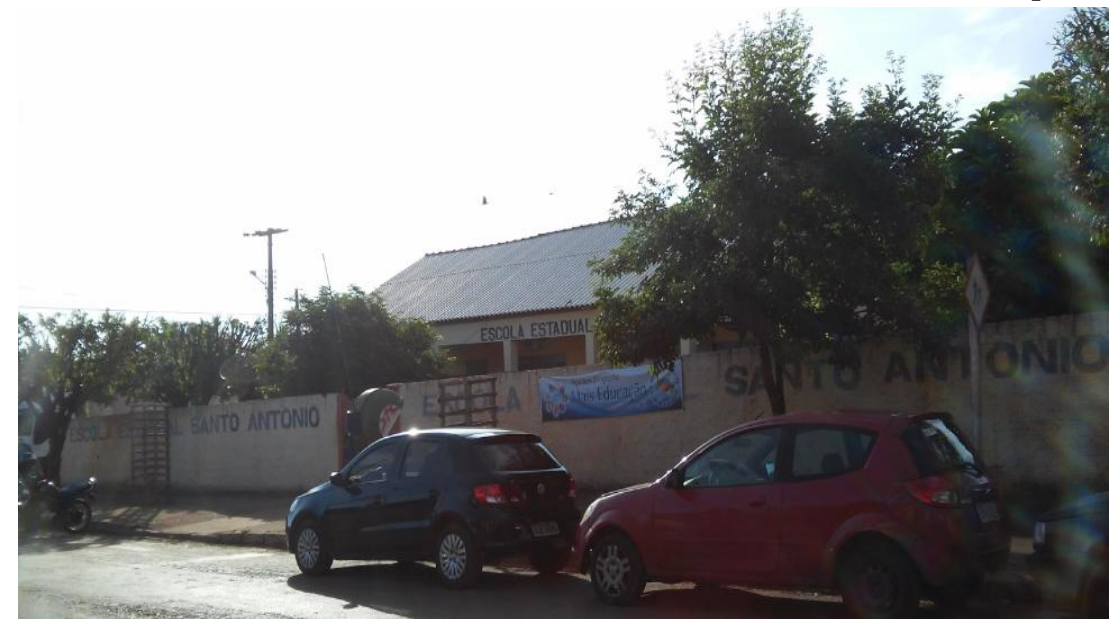

Figura 1: Imagem da entrada principal da Escola Estadual São Antônio.

Fonte: Gomes\&Oliveira. Dezembro de 2014.

da fundação deste estabelecimento de ensino, em regime de aluguel e que a partir de julho de 2008, passou a ter prédio próprio no mesmo endereço citado acima. Ao analisar a sociedade atual, implica pensar nas mudanças que ocorrem em todas as camadas sócio-politico-econômicos que colaboram muitas vezes para as desigualdades sociais, quebra de valores essenciais, preconceito crescente, desestruturação familiar, falta de respeito, de amor e a violência que assola os lares e o ambiente escolar. 
Todo este desequilíbrio reflete na aprendizagem e no relacionamento interpessoal na escola, que como instituição escolar, e como mediadora das diversidades, tem o objetivo de garantir uma educação de qualidade respeitando o indivíduo no seu processo de aprendizagem num contexto social. Constantou-se que a escola está trabalhando com atividades intermediadoras para promover um ensino de qualidade. A aplicação das Políticas Educacionais no contexto desta escola tem como motivo mudar a realidade vivida por estes alunos, tendo como objetivo propiciar uma perspectiva de melhora no ensino e na aprendizagem.

Atualmente ela oferece um bom ambiente para o trabalho escolar, porém necessita de algumas modificações para alcançar uma melhora na qualidade de ensino dos alunos, por exemplo, como as salas de aulas que necessitam de um espaço mais amplo, com equipamentos para favorecer uma maior ventilação, tudo sendo buscado para comportar melhor os estudantes. (PPP, 2014).

\subsection{Ciclo de Formação Humana}

Os ideais do Ciclo de Formação surgiu na França e foi trazido ao Brasil na década de 70, e foi gradativamente implantado no Brasil.Em Jaciara não foi diferente dos demais municípios do estado, o ensino ciclado começou a ser implantado em 1997, em reunião realizada na escola Marechal Rondon, a Escola Estadual Araujo Barreto foi a pioneira na implantação do ciclo, juntamente com as escolas municipais. Cabe-se as Secretarias de Estado de Educação coordenar e fiscalizar as ações escolares e o cumprimento da legislação vigente.

Conforme os estudos do PPP da escola e os PCN (1998) visam atender as seguintes necessidades dos alunos na escola: este currículo tem como finalidade acompanhar as atividades escolares como princípio educativo e está profundamente comprometido, simultaneamente, com as atividades discentes e com as atividades docentes.

O ciclo assume as atividades humanas como princípios educativos deste currículo, existe um estudo continuo sobre a reflexão da construção dos saberes necessários para a formação dos professores e automaticamente, dos alunos.

As Políticas Educacionais têm importante papel para a implantação do ciclo de Formação Humana, que busca atender o direito primordial da criança e do adolescente a educação:

\footnotetext{
No caso do Fundeb, a proposta de emenda constitucional se referia exclusivamente a ele. E foi amplamente modificada, com intensa atuação dos partidos de apoio ao presidente, especialmente o próprio PT, que contava com uma expressiva bancada ligada aos interesses da educação publica. Além disso, decorridos dez anos de vigência do FundeF, certamente haviam amadurecido as posições dos governos dos entes federados e das entidades educacionais da sociedade civil com relação a esse modelo financiamento da educação publica. Assim, se por um lado Fundef propriamente dito quase não precisou ser negociado, por outro o Fundef foi objeto de ampla negociação entre o legislativo e o Executivo, tendo sido este ultimo levado a concordar com mudanças importantes propostas pelos parlamentares (MARTINS, 2012; p.234).
}

Conforme o artigo 32 da LDB 9394, o Ensino Fundamental é obrigatório, com duração de 9 (nove) anos, gratuito na escola pública, iniciando-se aos 6 (seis) anos de idade, e terá por objetivo a formação básica do cidadão, mediante:

I - o desenvolvimento da capacidade de aprender, tendo como meios básicos o pleno domínio da leitura, da escrita e do cálculo [...]; III - o desenvolvimento da capacidade de aprendizagem, tendo em vista a aquisição de conhecimentos e habilidades e a formação de atitudes e valores; (p.17). 
Os direitos dos alunos como educandos devem ser cumpridos como direito de aprendizagem tornando-o cidadão. As escolas de Educação Básica no Brasil, com objetivo através dos incentivos das Políticas Educacionais visa erradicar o analfabetismo até 2020, com o Pacto Nacional da Alfabetização na idade Certa.

Conforme as normativas da SEDUC/MT (2014), os avanços a considerar na organização por Ciclos de Formação são as mudanças de concepções sobre o de ciclos de aprendizagens que romperam radicalmente com a lógica da escola seriada.

As exigências dessa nova concepção de avaliação rompem com os paradigmas das praticas pedagógicas desconexas com a realidade do aluno. A reprovação no seriado era uma barreira para a continuidade dos estudos por parte de certos alunos, a escola ciclada rompeu este paradigma que causava a evasão escolar no Ensino Fundamental.

\subsection{Formação Docente}

A profissão do professor é historicamente situada pelas Políticas Educacionais, necessita adquirir novas características para atender as novas demandas sociais e culturais.

O professor constrói sua identidade profissional através da didática em construção diante dos desafios da sala de aula Nóvoa (2009). É um processo de construção do sujeito historicamente situado - no reconhecimento social da profissão. A mobilização dos saberes didáticos do professor acontece na prática, através da experiência.

Porém ainda têm muitos desafios a enfrentar. O que dizer da autonomia de professores no Brasil de hoje? Segundo Contreras:

A autonomia dos professores, bem como a própria ideia de seu profissionalismo, são temas recorrentes nos últimos tempos nos discursos pedagógicos. No entanto, sua profissão estar-se dando, sobretudo na forma de slogans, que tal se desgastam e seus significados se esvaziam com o uso frequente.(CONTRERAS;2012, p.27)

Alguns profissionais conhecem técnicas e teorias, mas não utilizam por não se identificarem com a profissão ou com a escola/comunidade, atuam como meros coadjuvantes do ensino aprendizagem.

O papel do professor na escola de educação básica é inserir o aluno em sociedade, onde ele seja cidadão participativo. $\mathrm{O}$ ensino deve ser valorizado e sistematizado não só para suprir as necessidades do aluno na construção do seu conhecimento, mas também valorizar o profissional da educação, contribuindo com as melhoras das suas condições de trabalho e salário. (PIMENTA, 2012).

Ao analisar a formação docente nas últimas décadas no Brasil, perceber-se-á que as praticas pedagógicas sofrem constantes mudanças em seus paradigmas existentes entre a teoria e a prática de ensino.

\footnotetext{
A opção pelo recorte de 1940 a 2000 deve-se ao fato de se considerar que proposições e mudanças significativas ocorreram nesse período, quer no que diz respeito à realidade social, quer no que concerne às políticas educacionais que envolveram a realidade dos cursos de formação de professores. (BARREIRO; GEBRAN, 2012).
}

Os saberes da experiência socialmente acumulada da docência (mudanças históricas da profissão, a não valorização social e financeira, as dificuldades nas turmas e nas escolas), são representações e estereótipos que a sociedade tem dos professores. 
Estes são estereótipos a serem vencidos pela profissão nos cursos de licenciaturas. Segundo Nóvoa (2007); o qual discute a formação docente, aonde os professores sejam formados por professores. Assim, tem-se um novo olhar, fiel e solidário, e alguns passos são fundamentais para a compreensão deste processo.

\subsection{Práticas Pedagógicas}

Com a leitura das obras dos autores citados, e o PPP, do Regimento Interno, e do Plano de Ensino, entre outros, percebeu-se a importância de discutir as práticas pedagógicas e o que elas significam para os professores e a comunidade escolar. Como esses aspectos foram importantes para a reconstrução do ambiente escolar vivido na escola Santo Antonio? E sobre os conceitos de avaliação seja avaliação formal ou informal - o currículo dos saberes do ensino de Ciências e os procedimentos metodológicos ligados à organização do trabalho pedagógico da escola e do professor de Ciências.

Hoje o que se faz necessário ao professor para a prática na sala de aula no ensino de Ciências? Para Libâneo (2005), as práticas educativas não se restringem à escola ou à família, elas ocorrem em todos os contextos e âmbitos da existência individual e social humana. Para Freire (1997), a prática educativa, é algo muito sério, lidarmos com gente, com crianças, adolescentes ou adultos. "É pensando criticamente a prática de hoje ou de ontem que se pode melhorar a próxima prática" (Freire, 2002, p. 22).

Para Tardiff (2012), o professor deve assumir sua prática a partir dos significados que ele mesmo lhe dá, um professor que possui conhecimentos e um saber-fazer retirados de suas próprias experiências e a partir disso faz sua estrutura de orientação.

Por que os alunos dizem que é difícil aprender Ciências? O ensino de Ciências deve ser claro e objetivo, assumindo as funções de permitir ao aluno apropriar-se das estruturas de conhecimento científico e de seu potencial abrangente, quer seja no processo quer seja na aprendizagem.

Vygotsky foi um dos cientistas que se dedicou à vida e a descobrir como as pessoas aprendem. A competência exigida nos currículos para aplicação do ensino de Ciências nas escolas deve acontecer de maneira clara quando assumir as funções de permitir ao aluno apropriar-se da estrutura do conhecimento científico e de seu potencial explicativo e transformador.

As práticas pedagógicas devem ser envolvidas nas teorias e nos modelos teóricos para demonstrar conceitos científicos, muitas vezes ganham mais significado e importância para a sua inclusão nos currículos de saberes escolares das escolas PCN (1998). Os fundamentos científicos acabam muitas vezes não sendo assimilados pelos alunos devido à complexidade de seus conceitos durante a abordagem.

Surge então a figura do professor articulador, que também é membro do coletivo do ciclo. Não é um substituto do professor regente ou do coordenador, sendo assim:

Não possui uma turma fixa, trabalha com grupos de alunos provenientes das fases do ciclo e da superação que apresenta dificuldades na aprendizagem e necessitam de um planejamento participativo, consistente e rigoroso de acordo com sua necessidade, sem um valioso amparo ou Apoio Pedagógico (PAP). A função do professor articulador e investigar o processo de conhecimento e desenvolvimento do educando e atuar a partir dos dados e aspectos encontrados nessas investigações. Através disso, criar estratégias de atendimento educacionais complementares integradas as atividades desenvolvidas pelo professor regente. E cada Escola Ciclada possui um professor articulador a cada 6 turmas nos ciclos da escola este profissional da escola e escolhido pelo coletivo da mesma.(PPP, 2014, p. 09). 
A Escola Santo Antônio funciona em dois períodos, matutino e vespertino, tem em seu quadro professores, que trabalham no contra turno, oferecendo aulas de reforço aos alunos e além disso, conta com o apoio do professor articulador, que também assiste os alunos. A escola possui uma biblioteca cujo acervo está á disposição dos professores e dos alunos; mesmo não oportunizando o conforto aos visitantes, pois necessita de adequações, como mesas e cadeiras para estudo e um ambiente mais amplo. O laboratório de informática conta com vários computadores e outros equipamentos para o uso dos alunos e professores no processo ensino de todas as disciplinas.

A Escola participa do programa Mais Educação, que trabalha com os estudantes no contra turno, oferecendo aulas de letramento, horta, recreação e informática.

O Programa Mais Educação foi instituído pela Portaria Interministerial n.ำ 17/2007 e integra as ações do Plano de Desenvolvimento da Educação (PDE), como uma estratégia do Governo Federal para induzir a ampliação da jornada escolar e a organização curricular, na perspectiva da Educação Integral (Brasil Mais Educação (2014), pg.07).

Na tentativa de se levantar as possíveis hipóteses que dificultam a aprendizagem dos alunos no ensino de Ciências, surgiram dúvidas sobre como estão sendo realizadas estas práticas pedagógicas. Através disso a pesquisa visou compreender os motivos que não colaboram com não aprendizagem pelos alunos no ensino de Ciências. Com isso foi questionado uso do livro como o único recurso utilizado pelo professor.

\subsection{Livro Didático}

No livro “Didática, Currículo e Saberes Escolares" (2012) o texto de Tardiff traz os professores enquanto sujeitos do conhecimento, nesse texto fala-se sobre o professor que deve conhecer para ensinar, podendo ser criativo de forma que favoreça a construção do conhecimento pelo aluno.

O livro didático deve ser explicativo e transformador, de modo que garanta uma visão ampliada sobre os conceitos científicos, investigou-se as ferramentas didáticas utilizadas e o melhoramento nas práticas pedagógicas favoreceriam o processo de ensino - aprendizagem.

No entanto, ainda é bastante consensual que os livros didáticos são, na maioria das salas de aula, principal instrumento de trabalho do professor, onde o professor embasa significativamente as práticas pedagógicas. Esta pesquisa demonstra os procedimentos necessários para que o Livro didático possa ser adotado em uma escola, e quais os critérios de avaliação para a sua escolha.

De acordo com o MEC (Brasil, 2014); os materiais de ensino, e em particular o livro didático, tem papel relevante, e dentro dessa visão. Foram abordados os seguintes critérios que norteiam a escolha desse recurso fundamental na vida escolar.

O livro didático de Ciências é avaliado conforme a estrutura física e a organização do conteúdo que são os seguintes: a imagens presentes no livro didático; a Linguagem e o rigor científico, as Atividades Experimentais, a Evolução Histórica da Ciência; a Contextualização e abordagem metodológica dos conteúdos.

As escolas de Educação Básica da rede pública de ensino recebem, periodicamente, livros didáticos e outras obras literárias pelo Programa Nacional do Livro didático- PNLD, estas obras são adquiridas e distribuídas pelo Ministério da Educação para todo o país por intermédio do Fundo Nacional de Desenvolvimento da Educação (FNDE), através do apoio das Secretarias de Educação na fiscalização da qualidade física e pedagógica deste material, pedagógico. No que se trata da qualidade física e a estrutura material se este possui um filme plástico em sua capa (encapada) e a pedagógica se 
este não possui ideologias preconceituosas sobre conceitos, seja raça, localidade ou religião. Este Livro Didático será utilizado pelos alunos em um prazo de três anos, por este motivo sua escolha deve ser realizada com cautela.

O livro didático é importante ferramenta para transmissão de conhecimento, porém o professor não deve se tornar refém dele, por mais que seja de boa qualidade. Segundo Delizoicov (2009):

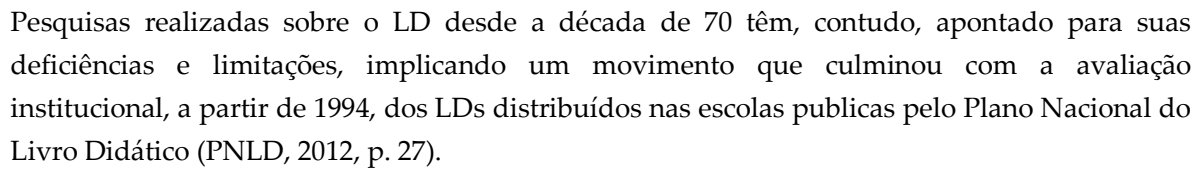

A integração das disciplinas de ciências é importante para a compreensão do conteúdo, tendo em vista que cada disciplina tem sua individualidade.

\footnotetext{
Segundo Bonatto (apud BRASIL, 1999, p. 89). A interdisciplinaridade não dilui as disciplinas, ao contrário, mantém sua individualidade. Mas integra as disciplinas a partir da compreensão das múltiplas causas ou fatores que intervêm sobre a realidade e trabalha todas as linguagens necessárias para a constituição de conhecimentos, comunicação e negociação de significados e registro sistemático dos resultados.
}

Devido os motivos, já citados, deve-se ter muito cuidado ao escolher o livro didático. Outro momento, em especial, é na hora de utiliza - ló nas aulas, para que ele não seja o único recurso pedagógico e acabe assumindo uma postura teórica e monótona, com apenas aulas expositivas. $\mathrm{O}$ livro didático é apenas um auxílio às práticas pedagógicas, possibilitando uma melhor aprendizagem ao aluno, cabendo ao professor à responsabilidade de apresentá-lo como fonte de pesquisa, descoberta, e vínculo com a realidade do aluno, no caso das Ciências, compreender e entender os fenômenos da natureza.

3 - Percurso Metodológico: contexto e sujeitos

Para a elaboração de qualquer projeto é necessário muita pesquisa para se obter um bom resultado. Segundo Marconi e Lakatos (1999) definem pesquisa exploratória como um grupo com três finalidades: 1 - desenvolver hipóteses; 2 - aumentar a familiaridade do pesquisador com o ambiente para a realização de uma pesquisa futura mais precisa; 3 - modificar ou clarear conceitos.

Contudo é preciso conhecer pesquisas que tiveram alguma contribuição. Segundo Martins (2006) a pesquisa bibliográfica trata-se de um estudo para conhecer as contribuições científicas sobre determinado assunto e tem como objeto recolher, selecionar, analisar e interpretar as contribuições teóricas já existentes sobre o tema.

Como esta pesquisa é um estudo de caso, foram feitos os levantamentos dos dados coletados junto à comunidade escolar. Entrevistou-se Diretor, Coordenador, Professor e alunos através de questionários com perguntas fechadas e abertas e também questionários avaliativos como parâmetros de avaliação significativa dos alunos no estudo de Ciências.

Para identificar as dificuldades, foram realizadas varias atividades. Inicialmente foram realizadas visitas à Escola Estadual Santo Antônio, no município de Jaciara-MT, onde observou-se a relação do professor com os alunos e presenciou-se aulas de Ciências no decorrer da semana, além de observar a metodologia utilizada pelo docente e suas práticas pedagógicas realizadas para o aprendizado dos alunos.

Após essas visitas, foram elaborados os questionários, para serem aplicados aos alunos, tendo como objetivo mensurar se os alunos aprenderam ou não conteúdos estudados no período e como o 
livro didático colaborou para a aprendizagem, visto que era o único apoio que o docente utilizava. Identificando suas dificuldades na aprendizagem Ciências.

A metodologia utilizada teve como caráter metodológico, a forma de pesquisa exploratóriodescritiva, com a percepção em sala de aula e o ambiente escolar sendo antecipada por levantamento bibliográfico. Tendo como perspectiva deste trabalho identificar se os alunos do $3^{\mathbf{0}}$ ciclo, nas etapas finais do Ensino Fundamental possuem dificuldades no aprendizado no ensino de ciências.

Segundo Gil (2010), uma pesquisa exploratória, muitas vezes pode ser identificado como pesquisas bibliográficas, estudos de caso e mesmo levantamentos de dados que podem ser considerados estudos exploratórios.

Dessa forma, a pesquisa se direcionou como um estudo caso. Esses estudos, segundo Gil (2010), têm como objetivo primordial:

\footnotetext{
O estudo de caso é uma modalidade de pesquisa amplamente utilizada nas ciências biomédicas e sociais. Consiste no estudo profundo e exaustivo de um ou poucos objetos, de maneira que permita seu amplo e detalhado conhecimento, tarefa praticamente impossível mediante outros delineamentos já considerados. (GIL, 2010, p.37).
}

Ao final, foram entregues os questionários aos alunos, sendo que aos alunos do $8^{\mathrm{a}}$ ano entregou-se questionário contendo 12 questões dissertativas e 07 de múltipla escolha e para os alunos do $9^{\mathfrak{a}}$ ano foram 24 questões de múltipla escolha.

Para a elaboração dos questionários, foi preciso verificar com o professor de Ciências, quais eram os últimos conteúdos que haviam sido abordados com alunos no semestre. E a correlação ao livro didático adotado pela escola. Em seguida realizou-se uma entrevista com os professores com o objetivo de abordar o tempo de atuação profissional de cada docente, e o mais importante, observar se eles, como profissionais da educação estavam observando se os alunos apresentavam dificuldades no processo de ensino - aprendizagem.

\section{Análises dos dados coletados e recursos alcançados}

Durante o período de observações e entrevistas na escola, levantou-se não apenas de não só os dados acerca do processo de ensino - aprendizagem, mas também a compreensão e atuação do professor na prática docente em seu contexto de atuação, a sala de aula, que deram oportunidades de diagnosticar como acontece o processo de aprendizagem; além dos motivos da dificuldade de aprender os conteúdos necessários para desenvolver as competências e habilidades dos alunos.

Assim foi proposto aos alunos da escola um questionário avaliativo, conforme o conteúdo adotado com a intenção de identificar se os alunos estão ou não aprendendo. Foram elaborados questionários para que pudessem responder sobre aos conteúdos que o professor havia passado recentemente.

A aplicação dos questionários foi realizada numa quarta feira, durante a primeira e segunda aula do período matutino. Presenciada pelos professores de Ciências aos 14 alunos do $9^{\circ}$ ano e aos 20 alunos do $8^{o}$ ano em sala de aula, após ser explicado o motivo da avaliação.

Durante aplicação, alguns alunos disseram que não compreendiam certos conteúdos porque não pareciam Ciências, mas Matemática. Outros disseram nem saber o porquê estudar Ciências, e se isto mudaria alguma coisa na vida deles, mas,também, houve outros que disseram gostar da disciplina e que as aulas eram sempre da mesma forma. Apenas tinham "aulas interativas quando iriam participar da "Feira de Ciências" na escola. Isso ficou muito claro porque aqueles que se 
interessaram, responderam todo o questionário e perguntaram quais eram as respostas corretas, depois que já tinham entregado. (Gráfico 1 e 2).

Gráfico 1 - Dados obtidos da turma do $8^{\circ}$ ano

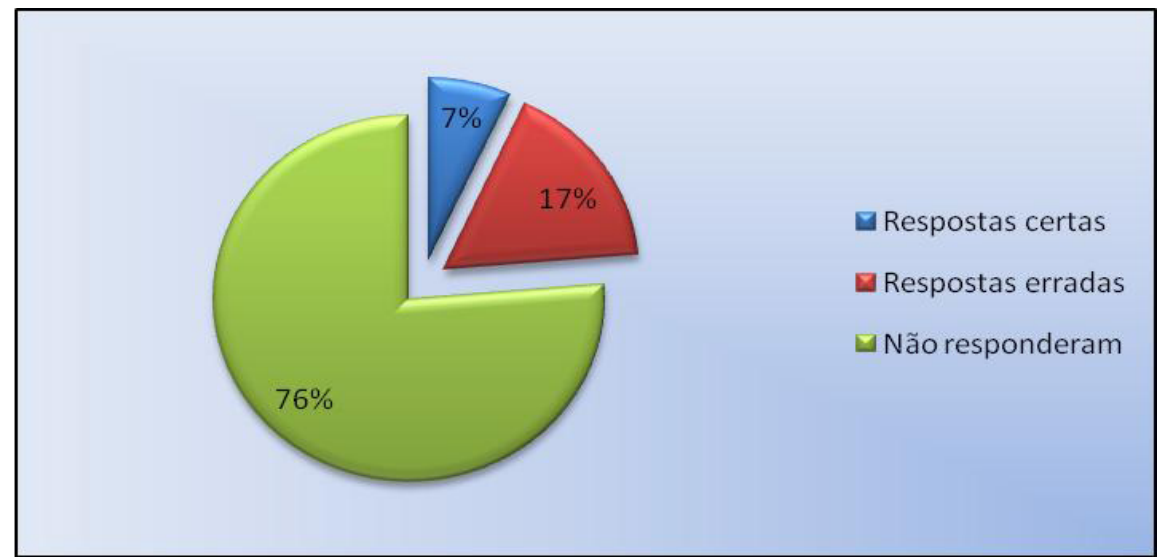

Fonte: Gomes \& Oliveira. Dezembro de 2014

Gráfico 2 - Dados obtidos da turma do $9^{\circ}$ ano

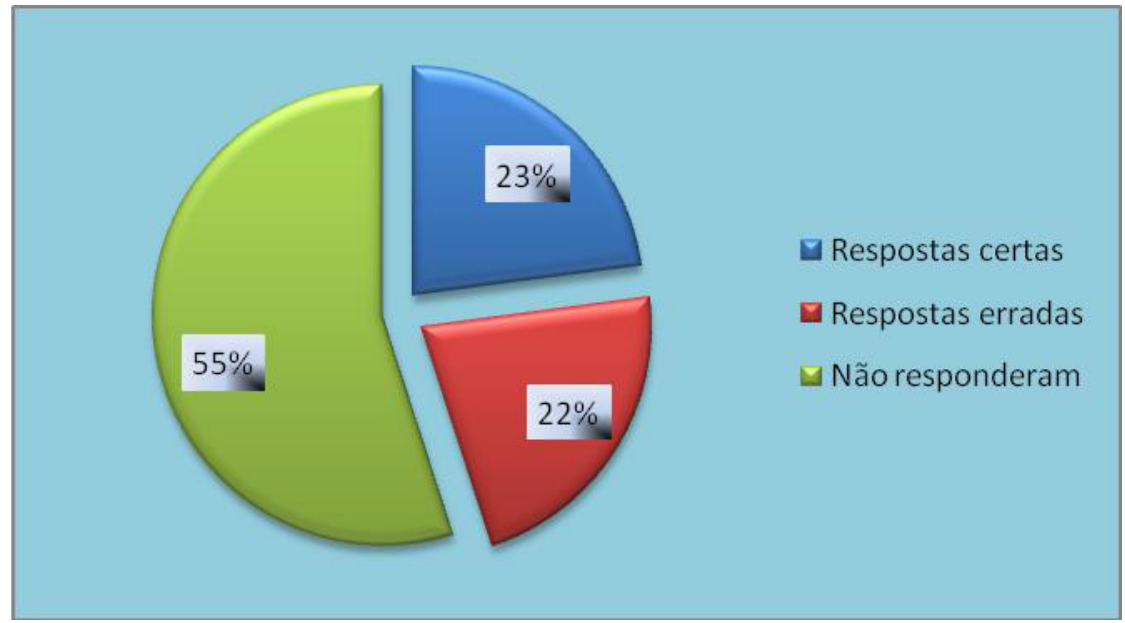

Fonte: Gomes \& Oliveira. Dezembro de 2014

Com os dados em mãos, observa-se que os alunos das duas turmas estão com dificuldades no aprendizado de ciências. Para que houvesse uma melhor compressão dos dados obtidos, foram colocados em dois gráficos abaixo, sendo um do $8^{\circ}$ ano e o outro do $9^{\circ}$ ano demonstrando o índice de cada turma:

Os questionários demonstraram que os estudantes não só estão apenas com dificuldades no ensino de ciências, mas também falta motivação para que eles possam interagir e compreender os conteúdos da disciplina.

Através de dados coletados, representados nos gráficos 1 e 2, sobre os conteúdos abordados em ciências vistos recentemente pelos alunos no $3^{\circ}$ e $4^{\circ}$ bimestre do ano de 2014.Observou-se que a falta de interesse dos alunos com os conteúdos de Ciências é muito grande, representado nos dois gráficos, pois ultrapassaram a margem de mais de $50 \%$ dos questionários que ficaram sem ser respondidos. Segundo Rubens Alves (2009): 
[...] as escolas de hoje em dia estão muito desinteressantes, sobretudo porque não estão lidando com questões cruciais da vida das crianças, ou seja, não estão aproveitando o seu entorno. As crianças têm interesse por aquelas coisas ao alcance de suas mãos. Não adianta trabalhar com abstrações. (p.28).

O questionário da turma do $8^{\mathrm{o}}$ ano abordou 03 temas, sendo eles relacionados ao Corpo Humano, a classificação dos Seres Vivos e o Meio Ambiente. E para o questionário da turma do 9o ano, também se abordou 03 temas, relacionados à Química e a Física, a Biologia e ao Meio Ambiente. Contudo o índice de acertos também foi muito baixo, porém houve uma melhora em relação aos alunos do $8^{\circ}$ ano.

Para melhor compreensão dos conteúdos respondidos pelos alunos, foram expostos em Gráficos como se classificou em relação aos temas abordados. Os gráficos 03, 04, 05 abaixo mostram como os alunos do $8^{\circ}$ ano se saíram nas avaliações.

Gráfico 3 - Índice de acertos do conteúdo relacionado ao Corpo Humano. $8^{\circ}$ ano

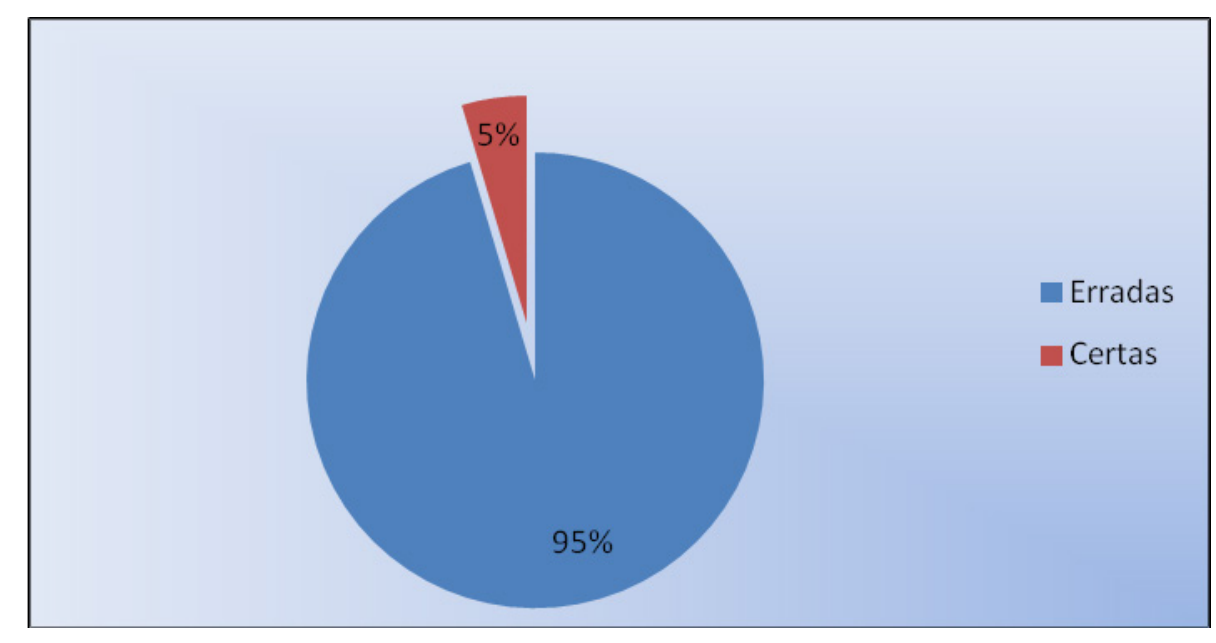

Fonte: Gomes \& Oliveira. Dezembro de 2014

Gráfico 4 - Índice de acertos do conteúdos relacionados ao Meio Ambiente. $8^{\circ}$ ano

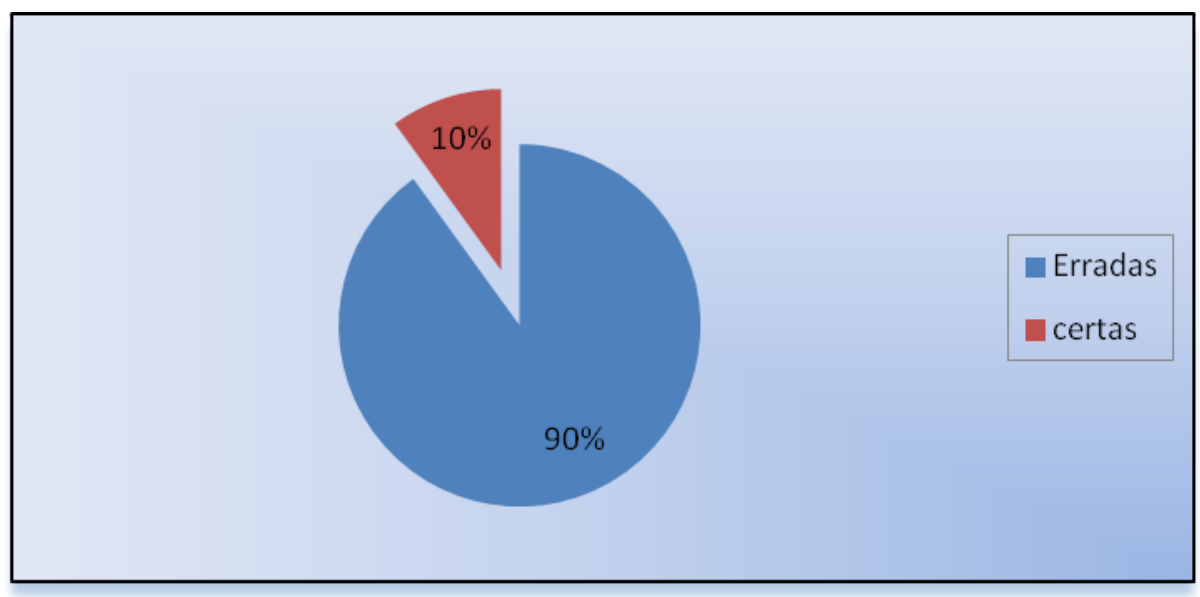

Fonte: Gomes \& Oliveira. Dezembro de 2014. 
Gráfico 5 - Índice de acertos do conteúdo relacionado ao Reinos. $8^{\circ}$ ano

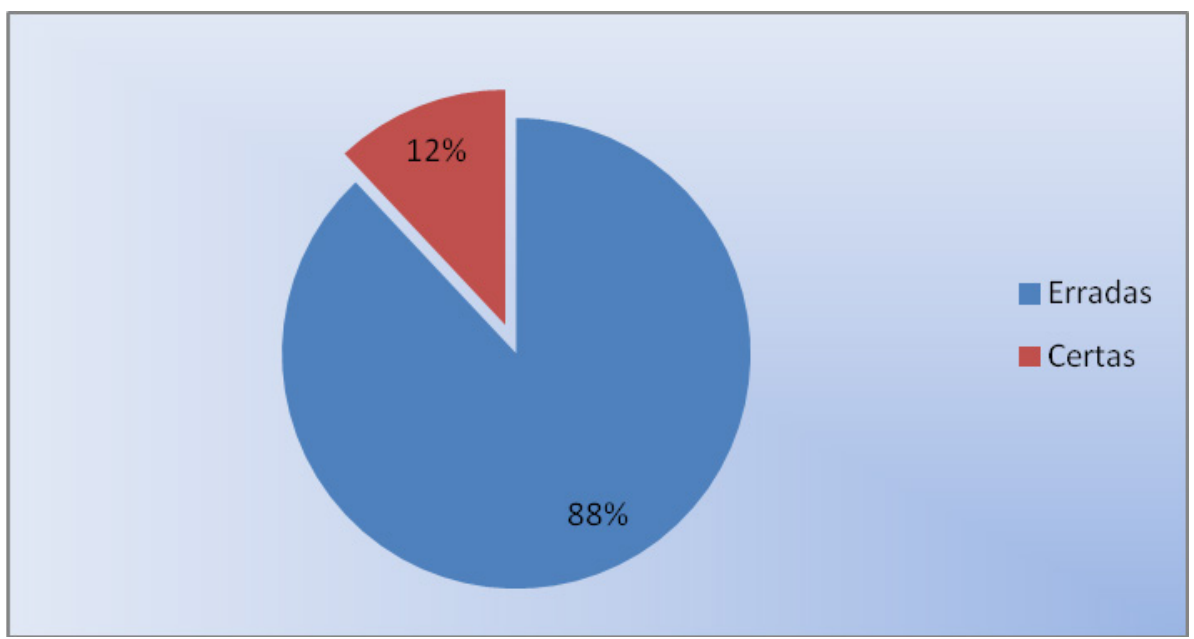

Fonte: Gomes \& Oliveira. Dezembro de 2014

Os alunos responderam os questionários, apenas alguns ficaram contentes em responder, porque para o restante, qualquer método avaliativo era como se fosse algo negativo, que seria apenas para reprova- lós e dizer-lhes que não conheciam o conteúdo em questão, isso está demonstrando a falta de interesse dos alunos, no alto índice erros de acordo com os gráficos. Os gráficos seguintes demonstram como os alunos do $9^{\circ}$ ano se comportaram em relação à aprendizagem de conteúdos estudados. Houve uma melhora significativa, pois esses alunos tem idade maior que os alunos no $8^{0}$ ano, demonstram um compromisso maior diante da avaliação entregue, responderam o questionário após lerem todas as questões e não apenas marcaram por se tratar questões múltipla escolha, provando maior comprometimento.

Gráfico 6 - Índice de acertos do conteúdo relacionado ao Meio Ambiente.9ํao a

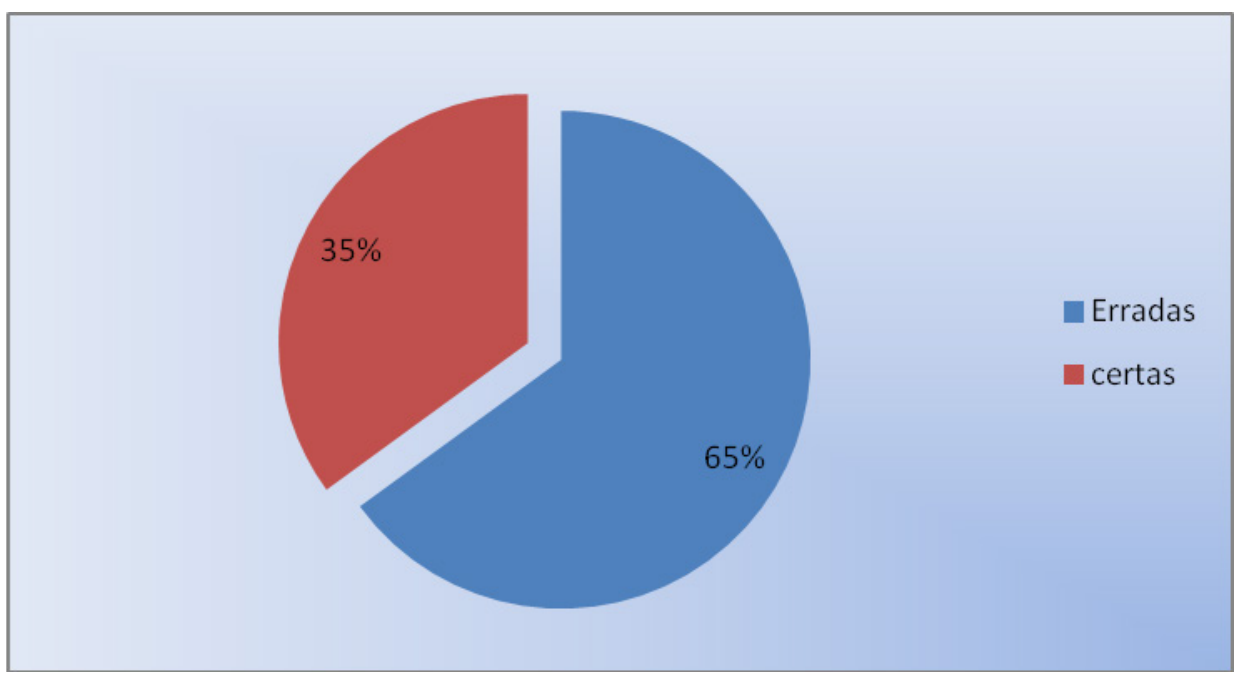

Fonte: Gomes \& Oliveira. Dezembro de 2014 
Gráfico 7 - Índice de acertos do conteúdo relacionado a Biologia. 9oano

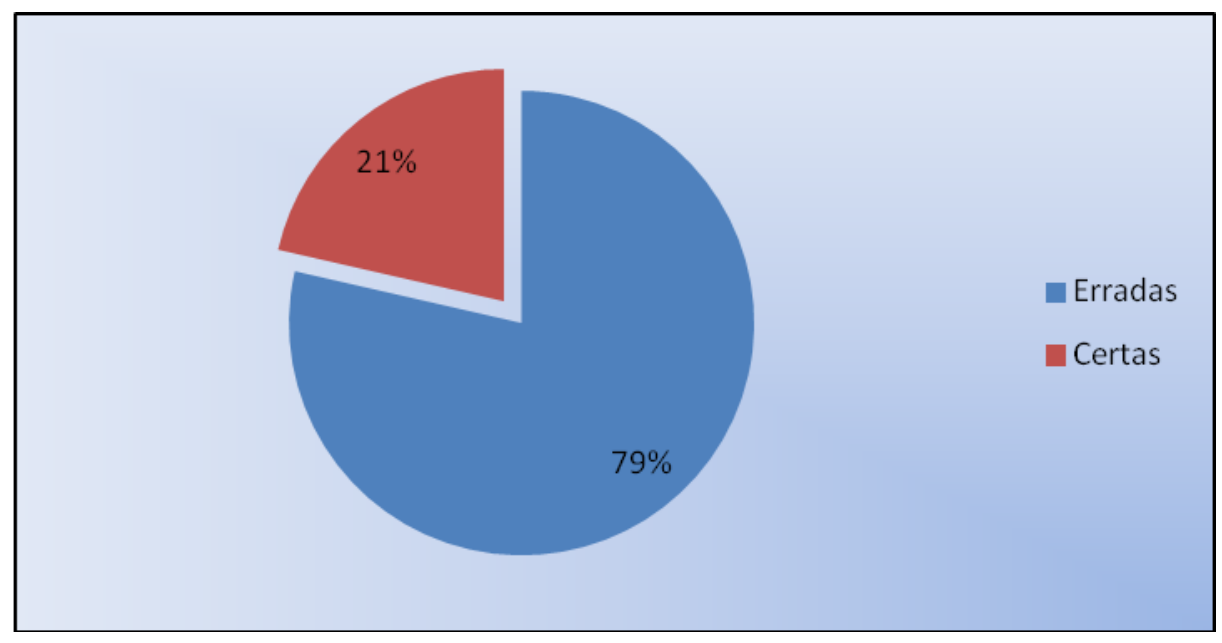

Fonte: Gomes \& Oliveira. Dezembro de 2014

Gráfico 8 - Índice de acertos do conteúdo relacionado a Química e Física. 9oano

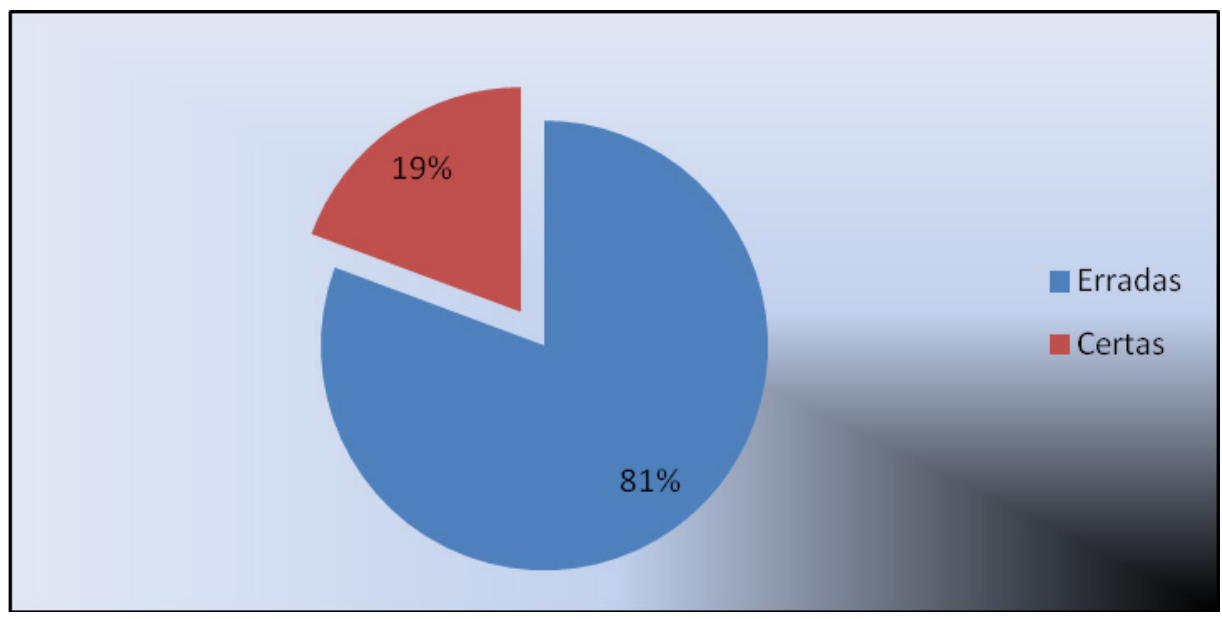

Fonte: Gomes \& Oliveira. Dezembro de 2014

Observando o baixo índice de acertos dos questionários realizados nas turmas do $8^{\circ}$ e $9^{\circ}$ ano, buscou - se através de questionários e entrevistas com os professores de Ciências, com a Direção, e a Coordenação da escola para saber como é feito o trabalho pedagógico. Para tanto, foi perguntado aos professores de Ciências, o que seria necessário para despertar o interesse dos estudantes no ensino de Ciências.

Segundo o Professor A - 26 anos. "Fazer o aluno entender que os conteúdos perdidos, podem fazer falta mais a frente, também chamando o aluno em outro horário para tirar algumas dúvidas".

Quando perguntados aos professores sobre os recursos tecnológicos da Escola ou quais tecnologias estão à disposição dos professores para os auxiliarem durante as suas aulas, e se os usos dessas tecnologias facilitavam a aprendizagem dos conceitos científicos estudados. O professor A - 26 anos - sua reposta foi : "Dispõem algumas tecnologias, como data show, computadores, multimídia, e quando os alunos estão interessados ajuda muito na aprendizagem". 
As perguntas referentes ao interesse do aluno pela escola, ao papel da relação professor/aluno e estímulo do professor, mostram que: o desinteresse dos alunos pela escola está relacionado à família, a eles mesmos e à escola, mostrando, assim, uma compreensão integrada dos participantes no que diz respeito à responsabilidade, pelo interesse dos alunos: explica o professor B - 47 anos: "Para uma escola dar certo preciso dos três pilares: a participação da família, dos professores, da escola e do interesse do aluno", no entanto não mencionou o que faz para motivar o aluno.

A comunidade escolar espera melhorar o nível de aprendizagem, permanência e diminuição da evasão apoiando-se em atividades propostas em Projetos financiados pelas Políticas Educacionais, então quando questionado, observaram diferença na aprendizagem a partir da instalação do Programa "Mais Educação" na escola, professor A - 26 anos - assim esclareceu: "A diferença do professor regente da disciplina e professor articulador, as diferentes facetas deste trabalho docente com os alunos, acontece de maneira articulado com os outros professores da escola. A diferença está no modo de trabalhar, eles trabalham ao ar livre, mais os objetivos são os mesmos de fazer com que nos programas fornecidos pela escola como o mais educação também se trabalha o ensino de ciências".E citou também que:

O programa foi implantado na escola devido o nota insatisfatória no IDEB (Índice de Desenvolvimento da Educação Básica) indicador da qualidade do ensino no Brasil e a escala é de 0 a 10 no aprendizado escolar em Português e Matemática. No ano 2009, a nota da escola foi 3,8 e a nota atual já é de 4,2. O índice subiu, porém precisa melhorar. Conforme os dados do IDEB 2014, esses são os critérios de avaliação pelas políticas sociais para melhoria da educação básica, e o gráfico a permite observar que meta é para 2022, e' que a média das escolas de Educação Básica no Brasil chegue à nota 6,0 como nos países desenvolvidos.

Gráfico - 09 - A evolução do IDEB no 2005 a 2002

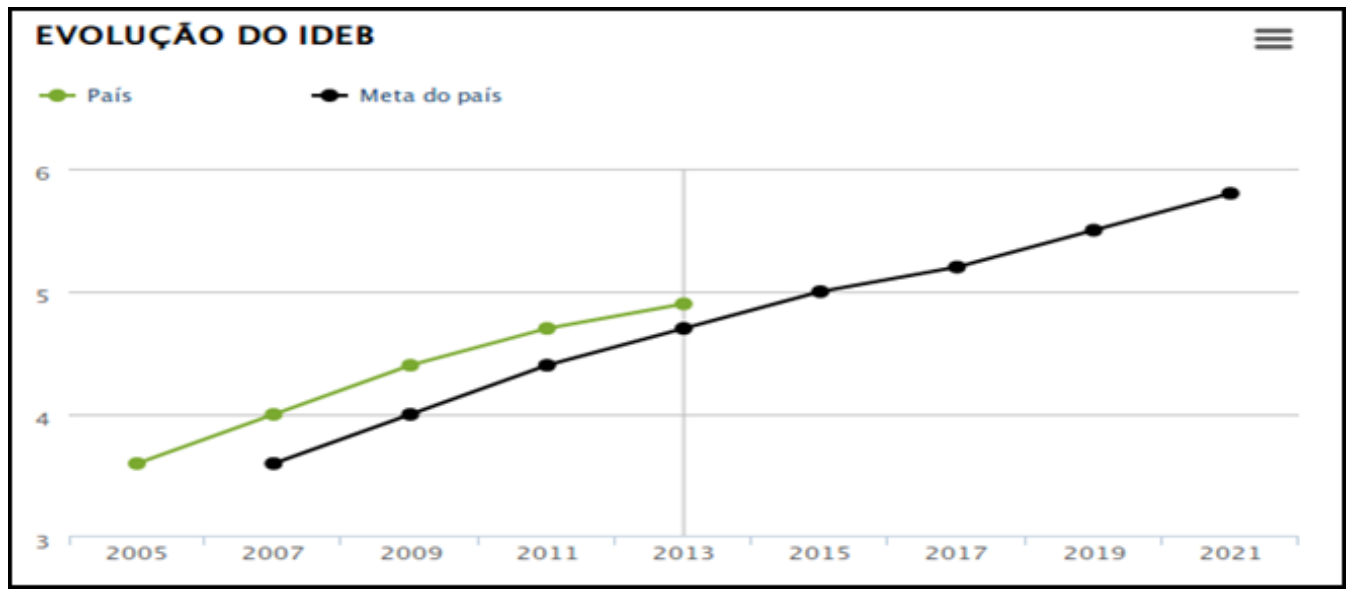

Fonte: QUEDU.pg.02 2014

O gráfico nesse caso conforme as notas vão aumentando os recursos financeiros irão diminuindo. O programa Mais Educação, visa diminuir a defasagem alunos no ensino, não somente nessas áreas, mas desenvolver também outras competências e habilidades.

Quando perguntado quais as dificuldades de ensinar Ciências, novamente o docente relatou a falta de interesse dos alunos, motivos da dificuldade de aprendizagem enfrentada por eles, quanto as dificuldades são as mesmas não só em ciências, mas em todos os conteúdos, pelo desinteresse dos alunos." Percebe-se nessa fala do professor - A - 26 anos, uma desmotivação aparente. 
Como despertar o interesse dos alunos, se através da sua prática pedagógica, cada professor tem autonomia de escolher qual a metodologia será utilizada. Segundo Castro (2004):

[...] "existe uma distancia entre Ciência realizada na escola e aquela das grandes universidades ou museus. Após revoluções educacionais e incentivas das políticas publicas no Brasil na década de 70 a 90 houve grandes mudanças ocorridas nos currículos de saberes das escolas de Educação Básica de Nível Fundamental" [...] Observadores da vida escolar preocupam-se com a distancia, às vezes imensa, entre a pesquisa cientifica e a pratica do ensino nas salas de aula. Focalizando o ensino de Ciências, pode-se dizer que todo o imenso esforço de investigação e experimentação que todo o imenso esforço de investigação e experimentação que levou as revoluções cientificas dos últimos séculos, poucas vezes tem penetrado na pratica escolar. (p.VII).

Através de diálogos com alunos constatou-se que as aulas dinâmicas na escola aconteciam somente em período do ano quando iriam participar de atividade externa da escola ou nas Feiras de Ciências de planejamento realizado com os outros professores, juntamente com coordenação de ensino. Assim relata professor - A - 26 anos: "As aulas são diferenciadas de acordo com as series, utilizando o microscópio, a computação e campeonatos de perguntas". Observou-se que as competências e as conceituações envolvidas nos modelos e teorias - que mais significativamente se mostrem relevantes e pertinentes para uma inclusão curricular dos alunos processo de aprendizagem PCN (1998). E como as habilidades dos alunos acontecem no decorrer do processo quando a competência ganha condições para se tornar uma habilidade.

Ao questionar o como professor se sentia diante da realidade vivida na escola e como reagiria se tivesse a oportunidade de mudar de profissão. Ouvi-se: "Nos sentimos desmotivados porque sempre buscamos o melhor para os alunos. Apesar de todas as dificuldades, não tenho interesse de ter outra profissão".

\subsection{Gestão Escolar}

Ao entrevistar a gestão escolar sobre o processo de aprendizagem dos alunos considerados indisciplinados e como poderia despertar o interesse deles pelo estudo, assim foi respondido pelos docentes - B- 47 anos e C- 51 anos: "Hoje os alunos estão voltados para um mundo tecnológico e as aulas precisam ser atrativas para despertar o interesse pelas aulas e coibir a indisciplina".

Observou-se que a escola não possui espaço físico para laboratório de Ciência e ao serem questionados como proporcionar Ensino de Ciências, os professores B e C relataram:

Conforme o professor B- 47 - anos, "A escola não possui laboratório, mas temos 02 corpos humanos, aparelhos diversos que trabalham órgãos podem trabalhar a escovação, microscópios, multimídias, etc".

Segundo o professor C - 51 - anos, "Não temos laboratório de ciências, mas a escola oferece alguns materiais como: Arcada dentária, microscópio, 02 esqueletos, torso e painéis com os sistemas do corpo humano".

O relacionamento do Diretor/Coordenador com os alunos é bom, dialogam constantemente sem atritos. Na tentativa de solucionar os problemas que possam vir a existir. Quanto aos professores: “O diálogo e a participação dos pais na vida escolar dos filhos é temida, pois mesmos, muitas vezes, se encontram com os avós ou outros responsáveis, para o cuidado com eles" (Diretor da Escola).

Como a Escola tem implantado o Ciclo de Formação Humana, isso prevê os cuidados necessários com os portadores de necessidades especiais, a inclusão é um importante passo que a 
educação assumiu diante dos obstáculos impostos na realidade desses alunos. Relatam os Professores B e C:

O professor B - 47 - anos, “Temos 07 alunos com necessidades especiais. Estudam na sala com os demais e no contra turno são atendidos em sala de recurso com a professora pedagoga".

Professor C - 47 - anos, "Sim, estão integrados com outros alunos, os professores buscam possíveis atividades para trabalhar com os alunos, os mesmos participam da sala de recursos e apoio pedagógico".

Buscou-se saber quais são os órgãos responsáveis pela fiscalização escolar, quais são as normativas repassadas pela Secretaria Educação do Estado Mato Grosso (SEDUC-MT), e se a secretaria da escola e os professores estão inteirados sobre esses documentos e as normativas pertinentes a educação, os projetos/atividades implementados, por esta Secretaria na escola. Interessou-se saber se a formação de professores para o Ensino de Ciências no Ensino Fundamental particularmente em relação ao uso das novas tecnologias. Relatam os Professores B e C:

O professor B - 47 - anos, "A partir de 2015 as escolas poderão ter um técnico/Multimeio Didático com 30 horas, semanais para auxiliar na organização e funcionamento do laboratório de informática; vídeos, acervo de DVD, data show, projetos, notebooks, tabletes, softwares educativos e demais equipamentos tecnológicos mediante apresentação de projeto constante no PPP da escola e ser encaminhado à superintendência de formação/coordenadoria de formação em tecnologia Educacional até 22/12/2014".

O professor C - 51 - anos, "A SEDUC oferece horas atividades para planejamento e acompanhamento pedagógico, não temos projetos na área de tecnologia. Porém, existem aulas planejadas, com alguns aparelhos e também no laboratório de informática".

Quais são os motivos da falta de interesse do aluno em estudar Ciências e qual seria o fator chave para não acontecer aprendizagem significativa. De acordo com o professor D - 52 - anos: “Agora pode falar a escola ciclada, os ideais foram importantes para diminuição da evasão escolar nas séries iniciais do ensino fundamental, mas nessa escola. Como em qualquer outra o interesse dos alunos é um tema recorrente dificulta a aprendizagem dos alunos. Esta é uma que não tem alta lotação e os alunos participam de projetos de socialização garantindo um maior tempo do aluno na escola" [...] "aqui os alunos vêm no contra turno no projeto mais educação. Então o aluno aprende se não quiser bem da verdade e a escola possui vários problemas sociais de ordem publica. Então a falta de interesse é o fator chave para não acontecer à aprendizagem dos alunos, eu penso que seja inclusive a principal delas. Com a falta de interesse deles acaba desmotivando o professor, prejudicando a relação com o professor".

As Políticas Educacionais contribuem para melhorar o aprendizado. Têm proporcionado melhora no ensino dos alunos de baixa renda, conforme o Professor D de 52 anos relatou: "Este tem sido objeto de estudo de repensar nossas ideias quanto às políticas sociais e publicas de ensino. Investimentos estão acontecendo, mas é preciso de toda a comunidade interligada. Para ter relevância para comunidade escolar" e quando indagado sobre quais as melhorias nas condições físicas da escola poderiam estar contribuindo para a realização das práticas pedagógicas na escola, ressalta o "Os recursos educativos de todas as escolas têm colaborado para melhoria no ensino. As salas arejadas e até mesmo climáticas irão melhorar as estruturas das escolas cada vez mais". 
A maioria dos professores atua como docente há muitos anos e todos eles de alguma forma sabem a diferença entre a escola ciclada e a seriada, e nos indagaram da seguinte forma: "todos sabem os pontos fortes e fracos dessas duas teorias, porém no ciclo de formação humana o seu principal objetivo é promover a inclusão social do ensino das diversidades". Nesta perspectiva temos que concordar que os alunos permanecem mais tempo na escola, o índice de evasão é baixo, porem a aprovação automática tira a autonomia do professor e provoca o desinteresse do aluno. São argumentos relevantes perante o que foi o relato.

O professor entrevistado atua nesta escola há 25 anos, e possui 32 anos de profissão como pedagogo no município. Além de possuir duas especializações em seu currículo. Segundo ele: "Prefiro trabalhar como Diretor, no momento estou aposentado da minha cadeira no estado, resolvi voltar à primeira escola onde comecei a profissão de docente. No final da carreira precisamos tranquilidade devido à vida agitada docência, mas a aposentadoria é triste para quem sempre teve várias ocupações no ambiente escolar".

Qual seria a melhor prática pedagógica que o professor deveria assumir? Professor D -51anos Assim respondeu: “A prática pedagógica é um tema a ser discutido. Já acontece e irá continuar a acontece e depende da didática de cada professor, porque as práticas pedagógicas é uma constante, a cada dia professor faz avaliação da sua prática". "Planejamento de aula - No estado o regimento de trabalho é de 30 horas, sendo 10 horas de hora pedagógica, o docente tem que planejar suas aulas, agora fica difícil o professor trabalhar em outra escola". "Dentro dessas dez horas atividades: elaboração de plano de aula, as aulas no contra turno quando há necessidade".

Como é caracterizado o planejamento do ensino de Ciências, é repensado todos os anos pelos professores para desenvolvimento das práticas pedagógicas da escola?

Conforme o professor - D- 52 anos, "Planejamento de ensino e trabalho coletivo que acontece consonante com outras disciplinas, e o coordenador de ensino acompanha não só o de ciências, mas todas as disciplinas os conteúdos que iram ser ministrados em sala de aula, por exemplo: um vídeo professor deve assistir antes dos alunos e mostrar para o coordenador ensino e o plano de aula da disciplina deve conter qual será objetivo deste para o conteúdo já ministrado ou a ministrar".

Ao ser indagado qual é a importância do livro didático para ensino de ciências? O relato do professor D - 52- anos, é expressivo quando diz: “O livro didático é uma peça fundamental, facilita o trabalho do professor, professor pode colocar os alunos para fazer leitura ou pré - leitura em casa e o professor faz o fechamento palavra final, o mais importante, o professor pode fazer uma boa escolha do livro didático como uma péssima escolha. Estrutura física do LD a capa e semi - plastificados se sujar você pode limpar, o conteúdo pode deve ser complementado com outros recursos pedagógicos e se o livro possuir algum déficit no próximo ano livro turma seguinte complementa a abordagem dos conteúdos".

No que concerne à tecnologia como computadores e celulares podem ser utilizados como meio de intermediador do ensino de Ciências, obtivemos a seguinte resposta do professor, "uso de celulares e computadores pode ser ferramenta benéfica para uso em sala de aula, desde que seja usado com cautela".

Conforme os professores da escola, o laboratório de informática, a figura 2 abaixo. É utilizado pelos alunos com agendamento do professor, seja o regente da sala ou professor articulador, uma vez por semana para cada turma, como descrito no planejamento. A escola usa o laboratorio para os alunos aprenderem a usar as ferramentas tecnologicas. O interesse dos alunos é visivel com essas aulas multidisciplinar. 


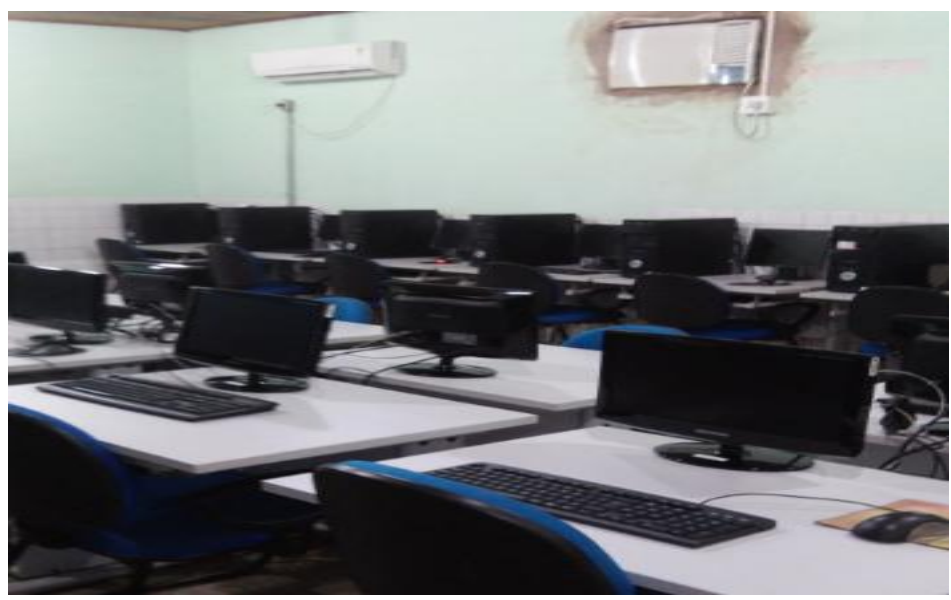

Figura 2 - Laboratório de Informática da escola Santo Antonio. Fonte: Gomes \& Oliveira. Dezembro de 2014

Conclui-se que ensinar Ciências do $6^{\circ}$ ao $9^{\circ}$ ano no Ensino Fundamental muitas vezes não é fácil, pois é nesta etapa dos estudos que os alunos estão sofrendo grandes transformações, sejam biológicas ou comportamentais estão indo para adolescência.

Nas palavras de Vygotsky há necessidade de uma reformulação, não só na didática aplicada ao ensino da disciplina de Ciências e correlatas, mas também em todas as demais disciplinas tanto no Ensino Fundamental, quanto no Médio.

Os alunos da $8^{\circ}$ série ano são mais agitados, estão na pré - adolescência, ainda não se sabe se são crianças ou adolescentes apesar de não gostarem de serem chamados dessa maneira, preferem serem chamados de adolescentes, porque para eles, crianças são inocentes. De acordo com Vygotsky (2007):

\footnotetext{
Cada matéria escolar tem uma relação que muda com a passagem da criança de uma etapa para outra. Isto obriga a reexaminar todo o problema das disciplinas formais, ou seja, do papel e da importância de cada matéria no posterior desenvolvimento psicointelectual geral da criança. (p. 117).
}

Além disso, o professor relatou consultar outras bibliografias de autores de Ciências sobre temas atuais, que abordam problemáticas relacionadas à realidade do aluno, mas ele dispensa a utilização outros recursos como réplica de esqueleto humano, microscópio, lousa digital entre outros recursos, alegando falta de tempo e desinteresse dos alunos.

Foi observada a metodologia do professor de Ciências em suas aulas, o modo de utilização do livro didático, a figura 3.

Foi observado que o Livro didático, é o único material didático utilizado nas aulas de Ciências, pelo professor e pelo aluno, e a relação de ambos com esse recurso didático é como único meio de aprendizagem. 


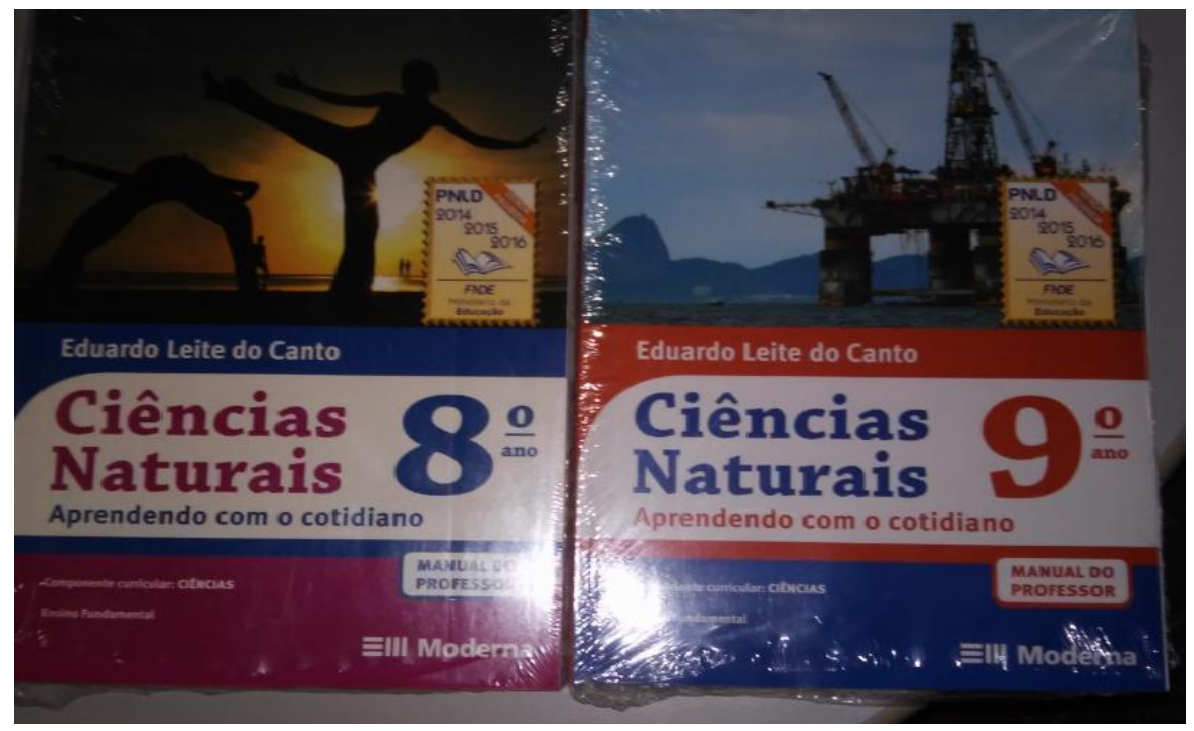

Figura 3 - Livros de Ciências utilizados pelos professores, o livro $8^{\circ}$ e $9^{\circ}$ ano Fonte: Gomes \& Oliveira. Dezembro de 2014

Observou-se que a relação professor/aluno encontra-se em constante conflito, prejudicando aprendizagem de Ciências. Esses atritos, juntamente com o desinteresse dos alunos, violência, falta de apoio familiar provocam desamino e poderá chegar até às patologias.

\section{Conclusão}

Verificou-se que o ensino de Ciências necessita da motivação do professor para o aluno aprender, mas não tem como ensinar quem não quer aprender, a relação professor/aluno é necessária para que aconteça o aprendizado. O professor deve o utilizar os recursos didáticos disponíveis como mediador no processo de aprendizagem, mas é necessário compromisso dos alunos em aprender.

Segundo os professores, e todas as legislações que regem a educação, a proposta do ensino por Ciclo de Formação Humana é boa, porém todos sabem das fragilidades que o sistema oferece, as informações sobre o processo de ensino-aprendizagem foi adquirida na troca de experiências com os pares e algumas leituras individuais realizadas pelos graduandos.

Existe ainda uma grande distorsão sobre o Ciclo de Formação Humana. A maioria dos professores se guiam pelo "Sensu Comum", dizendo que eles na podem fazer porque a progressão é automática. É aís que impera o equívoco. O aluno dentreo de cada Ciclo deve ser promovido levando automaticamente a dependência que deve ser cursada no contraturno ou seja no turno contrário ao que o aluno estuda normalmente. Se isso ocorrer, serão vencidas as dificuldades e acontece a , evitando que ao final do Ciclo haja retenção.

O objetivo do Ciclo é evitar que o aluno seja punido, repetindo o ano, quando a dificuldade do mesmo é entre uma a três disciplinas. O necessário ' $r$ a leitura de cada cidadão que ainda não entendeu o ciclo, dessa forma a escola irá melhorar e os alunos aprenderão mais. aprendizagem

Os resultados obtidos revelam ainda que: a escola pública precisa problematizar o processo ensino-aprendizagem; os alunos não se interessam pela escola, porque não veem relação entre os conteúdos ministrados nas aulas e a vida, o futuro. Sendo assim, acredita-se que a escola deva atuar 
como uma instituição transformadora que venha se estruturar para atender às necessidades da sociedade do século XXI.

\section{Agradecimentos}

À Coordenação de Aperfeiçoamento de Pessoal de Nível Superior (CAPES) pelo subsídio através do Programa de Consolidação das Licenciaturas (PRODOCENCIA) Edital 019/2013, processo № 113.657, e do Programa Institucional de Bolsa de Iniciação à Docência (PIBID) Edital № 061/2013, processo № 128.570, IFMT/Campus São Vicente/Sub Projeto Ciências.

\section{Referências}

ALVES; Rubens. O Desejo de Ensinare a Arte de Aprender Disponível em: http://www.educardpaschoal.org.br/web/upload/NossosLivros/68 livro desejodeensinar(1).pdf. Acesso em: 25 de fevereiro de 2015.p28.

AZANHA, Jose Mario Pires. A formação do professor e outros escritores. São Paulo: 2006. Editora SENAC São Paulo pg.53.

BARREIRO F.M.I; GEBRAN.A.B; Pratica de Ensino e Estagio Supervisionado na Formação de Professores: 4. Programas de Estagio. São Paulo: Avercamp, 2012 p.37.

BONATTO, Andréia. BARROS, Caroline Ramos. GEMILI, Rafael53 Agnoletto. LOPES, Tatiana Bica. FRISON, Marli Dallagnol. Interdisciplinaridade no Ambiente Escolar. IX ANPED SUL, Seminário de pesquisa em educação da região sul. 2012. Disponível em: http://www.ucs.br/etc/conferencias/index.php/anpedsul/9anpedsul/paper/viewFile/2414/501.

Acessado em: 01 de outubro de 2014.

BRASIL, LDB. Lei de Diretrizes e Bases da Educação Nacional. Disponivel em: http://www2.senado.leg.br/bdsf/bitstream/handle/id/70320/65.pdf. Acessado em: 15 de março de 2015.p.17.

BRASIL. Cadernos das Portarias 2014 SEDUC. Normativas de 2014. http://www.seduc.mt.gov.br/educadores/Documents/Gest\%C3\%A3o\%20de\%20Pessoas/Normativas\% 20Ano\%20Letivo\%202014/Caderno_de_Portarias_2014.pdf. Acessado em: 19 de fevereiro de 2015.

BRASIL. Implantação do Ciclo de Formação Humana: Mato Grosso. PORTARIA № 453/11/GS/SEDUC/MT. Disponível em: http://www.seduc.mt.gov.br/educadores/Documents/Gest\%C3\%A3o\%20de\%20Pessoas/Normativas\% 20Ano\%20Letivo\%202012/PORTARIA\%20N\%C2\%BA\%20453.pdf\#search=ciclo\%20de\%20forma\%C3\% A7ao\%20humana\%20portaria. Disponível em: 19 de fevereiro de 2015.

BRASIL. Passo a Passo. Mais Educação. Disponível em: http://portal.mec.gov.br/dmdocuments/passoapasso maiseducacao.pdf. Acessado em: 25 de fevereiro de 2015.

BRASIL. Políticas Públicas Educacionais: conceito e contextualização numa perspectiva didática. Disponível em: http://www.sinprodf.org.br/wp-content/uploads/2012/01/texto-4-pol\%C3\%8Dticasp\%C3\%9Ablicas-educacionais.pdf. Disponível em: 19 de fevereiro de 2015. 
BRASIL. PREFEITURA MUNICIPAL DE JACIARA-MT. Secretaria Municipal de Educação, Cultura e Disporto. Projeto Político Pedagógico (PPP) da “Escola Estadual Santo Antônio". 2014.

BRASIL. Programa do livro didatico. http://portal.mec.gov.br/seb/arquivos/pdf/Avalmat/pnldapres07.pdf. Disponível em: 19 de fevereiro de 2015.

BRASIL. Quedu Academia. IDEB. Disponível em: http://academia.qedu.org.br/ideb/diagnostico-eacao/. Acesso em: 28 de fevereiro de 2015.

BRASIL. Secretaria de Educação Fundamental. Parâmetros curriculares nacionais: Ciências Naturais/Secretaria de Educação Fundamental. Brasília: MEC/SEF, 1998. 138p.

CASTRO, Amélia Domingues. Ensino de Ciências: Unindo a pesquisa e a pratica. Prefacio. -1 Ed. SP: Pioneira Thomson Learning, 2004.p.VII.

CONTRERAS, J. A autonomia de professores. São Paulo: Cortez, 2012 p.27.

DELIZOICOV, Demétrio. ANGOTTI, José André. PERNANBUCO, Marta Maria. Ensino de Ciências fundamentos e métodos. São Paulo: 2009. Editora Cortez.p.27

FREIRE, Paulo. Pedagogia da Autonomia, Saberes Necessários a prática Docente. São Paulo -SP ano da publicação original 1996. Ano da publicação digitalizada 2002.

FREIRE, Paulo. Professora sim, tia não. São Paulo - SP - Editora: Olho d'água. 1997.

GIL, Antônio Carlos, Como Elaborar Projetos de Pesquisa. $5^{\circ}$ Ed. São Paulo, SP: Editora ATLAS S.A, 2010 pg. 25 - 37.

LIBÂNEO, José Carlos. Pedagogia e pedagogos, para quê?. São Paulo - SP - Cortez, 2005. 8 ed.

MARCONI, M.A.; LAKATOS, E.M. Técnica de Pesquisa. 4ª ed. São Paulo: Atlas, 1999, p.19.

MARTINS, Gilberto de Andrade. Estudo de caso: uma estratégia de pesquisa. São Paulo: Atlas, 2006.p.33.

MARTINS, Ricardo Chaves de Rezende. O poder legislativo e as políticas publicas educacionais no período 1995-2010.3 Ed. Brasília, GO: Edições Camara, 2012 p.34.

NÓVOA, Antônio. Desafios do trabalho do professor no mundo contemporâneo. - São Paulo - SP 2007.

PIMENTA, Selma Garrido. O estágio na formação de professores: unidade teoria e prática. $-11^{\circ}$ Ed. - São Paulo. Cortez, 2012.

TARDIF, Maurice. Saberes docentes e formação profissional. - 13ํㅡㄹ Ed. - Petrópolis, RJ: Vozes, 2012.

VISGOSTSKY, Lev Semenovich, 1897-1934. A formação social da mente: o desenvolvimento dos processos psicológicos superiores. $7^{\circ}$ Ed. São Paulo, SP:Martins Fontes, 2007pg.156 e 157. 